20. Pearce, J. Some contemporary issues in social accounting and audit [Text] / J. Pearce // Social and Environmental Accountability Journal. - 2002. - Vol. 22, № 1. - P. 1-7. doi:10.1080/0969160x.2002.9651665

\section{ИССЛЕДОВАНИЕ ГЛАВНЫХ ЛРЕИМУЩЕСТВ В СОЦИАЛЬНО-} ОРИЕНТИРОВАННОМ УЧЕТЕ

Исследованы главные преимущества социально-ориентированного учета. Акцентировано на необходимости расширения границ социализации учета в отраслях национальной экономики Украины, особенно в период проведения реструктуризаций и других структурных изменений, которые требует современная мировая экономика. Проведен сравнительный анализ социальных отличий между двумя учетными системами: СССР и УКраины. Предложена главная составляющая социально-ориентированного учета - качественная, способная поднять уровень эффективности экономики на микроуровне и макроуровне.

ключевые слова: социальный учет, реструктуризация, отраслевой учет, учет в СССР, знак качества.

Shkulipa Ljudmyla, PhD, Assosiate Professor, Department of Theory Accounting, National Academy of Statistics, Accounting and Auditing; Kyiv, Ukraine, e-mail: Bezysa@gmail.com, ORCID: http://orcid.org/ 0000-0002-4784-9955

\section{Shiryaeva L., Khotyeyeva N., Chiz L., Bondarenko V.}

\title{
ANALYSIS OF ACCOUNTING OF FINANCIAL EXPENSES IN THE PROCESS OF FINANCIAL PLANINING OF TRANSPORT COMPANIES
}

Предметом роботи є практичні аспекти фінансового планування транспортних компаній. Проведено аналіз факторів впливу на параметри процесу фінансування капіталомістких підприємств, до яких належать портові підприємства та судноплавні компанії. Розглянуто стан та умови на фінансових ринках для залучення додаткового фінансування в першу чергу для судноплавних компаній. Зміни умов фінансування необхідно враховувати у процесі фінансового планування, насамперед рівень фінансових витрат та рівень ризику.

Ключові слова: фінансові витрати, фінансування капіталомістких підприємств, фінансове планування, рівень ризику.

\section{Introduction}

The state of the external environment complicates the process of financing of capital-intensive companies, which include port and shipping companies, primarily political risks, the economic legislation of the country, changes in the international financial market and the maritime market. Under such conditions, if the company wants to raise enough funds to increase the volume of its means of production, attracting investments at a low interest rate and controlling risks in financing its activities, all aspects of financial planning must be carefully worked out, primarily the level of financial costs and the risk level.

Risks substantially limit the desire of financial intermediaries to lend and the amount of financial resources for transport companies. The terms of long-term financing can offset the positive effect of the financial leverage, as a consequence, the planning process should be more flexible.

\section{The object of research and its technological audit}

The object of research is the process of financial planning of transport companies in terms of financial costs.

Financial planning must take into account, in modern conditions, first of all, external factors. In order to implement an effective financial planning process, conduct research on the conditions for raising funds in financial markets. The problem aspects of the financial planning system at transport companies are considered. Conditions of reception of financial resources of the transport companies are considered.

\section{The aim and objectives of research}

The aim of research is to review and analyze the main factors influencing the size of financial resources of companies and the conditions for implementation of effective financial planning.

To achieve this aim, the following tasks are defined:

1. To analyze the Ukrainian market.

2. To analyze the possibilities for obtaining financing from the banking sector.

3. To give recommendations on the accounting of the financial situation in the financial planning process of the transport companies.

\section{Research of existing solutions of the problem}

In general, the focus of practitioners is on the formation of the optimal structure of capital, cost management, optimization of management structures and management decisions [1-12]. 
General features of financial planning and scientific approaches to formation of a financial planning system with varying degrees of detail are examined by different authors [1, 2, 10]. Methodical bases and practical recommendations [1] of the system of financial planning of automobile transport companies are developed. However, experts [11] note the need to optimize the costs of transport companies. Financial analysts [7] declare that financial institutions do not want to conduct long-term loans to companies and the level of rates does not change significantly, which increases the financial costs of transport companies, reduces the level of efficiency and can affect the financial sustainability of companies [12].

Analysis of the specifics of financial planning in maritime transport companies is not given enough attention. The models proposed in the theory of financial planning are of a general nature and do not take into account the industry specificity of companies of this type of transport.

\section{Methods of research}

To achieve this aim, such general scientific and special methods and methods of investigation are used: generalization, analysis and synthesis - for research of the relations of transport companies with financial markets, abstractlogical for theoretical generalization and formulation of conclusions.

\section{Research results}

Transport companies are experiencing difficulties in attracting investments in modern conditions. Even if operations are effective, and the level of financial stability is high enough, its investment attractiveness is a matter that is solved taking into account the influence of external factors in the first place. The negative influence of external factors, in turn, is risks, the ways of protection from which are rather difficult to find in the investment projects.

According to the experts' calculations [5], a stagnant world trades, a decrease in activity in investment activities and an increased uncertainty of politics have become another difficult step for the world economy. Moderate recovery is expected in 2017 , however, if commodity markets are not activated, then for transport companies, the increase in activity volumes is also undefined. While the financial incentive may increase global growth above expectations, the risks to growth forecasts are still shifted toward deterioration. Important risks of deteriorating the situation stem from the increased uncertainty of the policies in the main countries.

In Ukraine, the cost of attracting additional funding (interest rate) has an increasing dynamics (row 1) in comparison with the states of the European Union (for example, Estonia - row 2) (Fig. 1).

However, according to the findings of experts [7], according to the NBU and to the results of 2016, the average rates on hryvnia loans to business customers declined from $20 \%$ to $16 \%$. That is, the loan drops a further $1-2 \%$ before the spring. "The main problem is not the cost of loans, but the complexity of obtaining them. Banks strictly assess the applications and are ready to lend only for short terms - there are almost no programs with terms more than 1-3 years» [7]. However, transport companies need financing for development, which requires long-term relationships. The heavy structure of assets significantly affects the level of liquidity indicators, which also does not contribute to raising the company's credit rating (According to the data [6]).

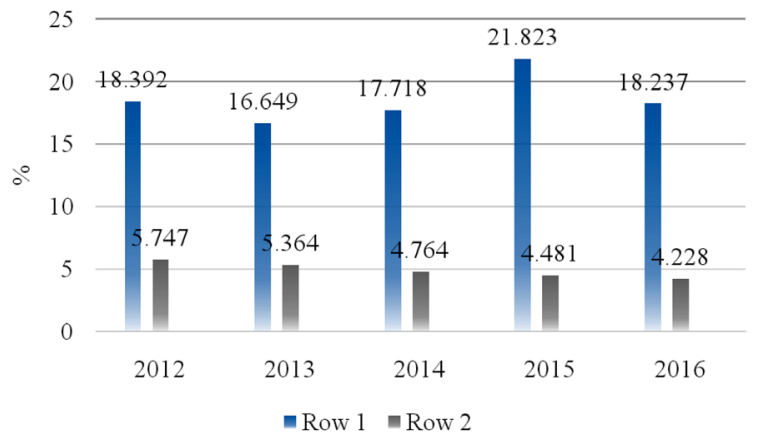

Fig. 1. Dynamics of the interest rate level. Source: author's development (according to data [6])

According to the expert [7], serious changes in the market can be expected by the end of the year: «If our economy continues to stabilize, by autumn we can expect new bank offers with cheaper rates on loans».

Transport companies have access to various financial markets with a different mechanism for obtaining resources. For example, shipping is a capital-intensive and risky business, on the one hand, shipping companies need a significant amount of financing to modernize the fleet in order to maintain the necessary level of competitiveness, but in the maritime industry for financial institutions investing is more risky than in the other sector of the economy.

There are a huge number of transport companies with financial difficulties that do not have the opportunity to raise funds from external sources to finance the production process and development of the material base. Companies can obtain the necessary funds on acceptable term with the participation of financial institutions, it is profitable to invest temporarily free funds in various financial transactions. Any financial intermediary, providing borrowers with services for obtaining the missing resources, and creditors - for placing free money, pursues only its own interests. A complex intersection of interests arises, and a financial project can only take place when the terms of cooperation are acceptable to all parties. An understanding of the essence and role of financial intermediaries is necessary for success in the financial management of the company.

In addition to objective, subjective factors play a role in decision-making. Any investor, assessing the attractiveness of investments, uses its approach to valuation. Financial institutions make investment decisions, they ask not only information about the company's revenues and history, but also a full account of the company's debts, which complicates the financing process and, consequently, the company's activities.

There are many ways to finance the activities of transport companies, various methods for calculating the credit rate, with a certain period and the mechanism for return on investment, as well as other conditions.

The company's ability to service the attraction of funds from various sources depends on the effectiveness of its activities. 
The decision on the capital structure is based on a thorough and varied forecast of revenues and expenditures. High and constant level of income allows to reduce the dependence of the company on external sources, but at the same time allows on the other hand to use cheaper and more risky sources of financing.

In the economic downturn, the company's owners are more critical about the company's development projects. For example, research shows that managers are reluctant to go for an additional share issue, if this leads to a dilution of the earnings per share [1].

Formally, creditors claim only a part of the company's income (usually fixed) and do not interfere with the management of its activities. However, if significant borrowed funds are involved as a source of financing, using various conditions and restrictions specified in contracts (for example, providing shares as a pledge of the company, prohibiting an increase in debt and paying dividends, etc.), lenders can exert significant pressure on the owners and management.

Financial planning for example for a shipping company is an optimal choice of one of many practical schemes, and an equilibrium between the minimum costs and the minimum risk that can maximize the expansion of the company for a certain amount of money, as illustrated in Fig. 2.

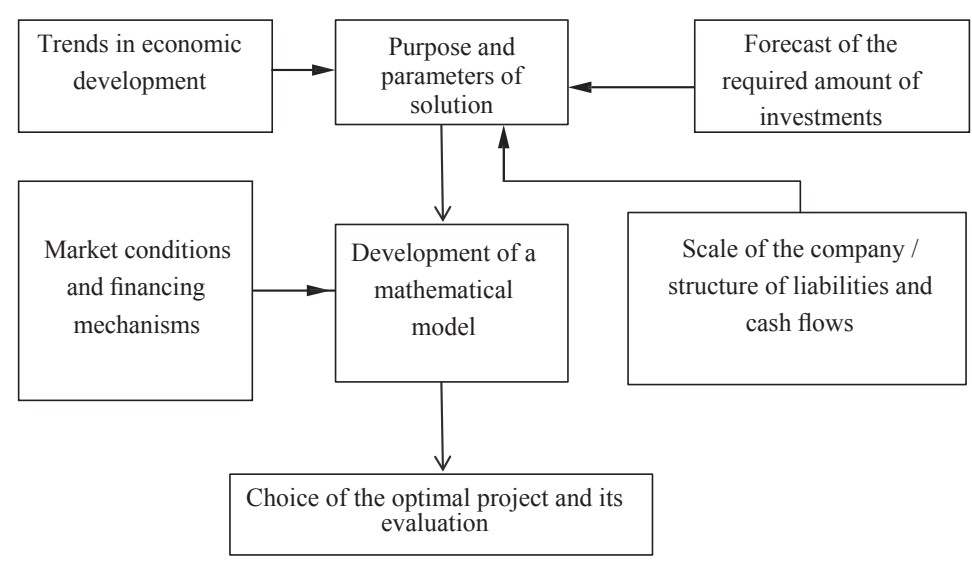

Fig. 2. Stages of the financial planning process (own development)

Any shipping company must follow the basic rules in the field of financing its activities:

1. Moderate amount of necessary capital.

2. The lowest cost of financing capital investments.

3. Optimum capital structure.

4. Variable ways of attracting capital.

These rules can help the company to form an optimal financing structure, make full use of capital, independently develop and react to market changes.

It should be noted that formation of the company's budget should take into account changes in the way of attracting capital.

Transport plays an important role in ensuring stable and sustainable development of the economy, ensuring the strengthening and optimization of market links of economic entities.

Development of transport companies of the country is characterized by complex processes occurring in the industry.
In the global financial crisis, the number of banks that are actively cooperating with shipping companies has significantly decreased. The reasons, including, were also included in a large number of unreturned loans. The success of the bank's operation depends on many factors, among which the most important is the credible lending policy, including the choice of clients, the strength of the ties with it, knowledge of the specifics of financial management in the relevant areas of business, etc. Companies-borrowers should carefully study and take into account differences in credit policy of specific financial institutions, based on the peculiarities of the positions of banks and their leaders for the following aspects: loan risk, the debt-to-equity ratio, the total amount of the possible loan, the degree of loyalty and, most importantly, the «human factor». All this determines the risk that the bank is ready to go to. Significant economic changes are a consequence of the last financial crisis, which affected, first of all, the company's capitalists. Shipping companies do not have the resources to finalize the payment for the started projects.

Before the global crisis of 2008-2009 there was a sharp increase in contracts for building of new ships, caused by a record high rates and tariffs on freight markets. The income level formed the conditions for increasing the inflow of loan capital. At the same time, many companies started large-scale programs for replenishment of the fleet, accompanied by huge shipments of new tonnage, which did not correspond to the real needs of international shipping. The shipyards barely managed to cope with the influx of orders and continuously increased shipbuilding capacity. The pace of development of the world merchant fleet was sharply accelerated and significantly exceeded the moderate growth in demand for maritime transport.

Many shipyards still continued to properly perform previously concluded contracts in the post-crisis period of 2010-2012. The further influx of surplus tonnage into the world fleet, with the help of the newest high-performance ships, caused a sharp deterioration in the market conditions, a collapse of rates, a prolonged disruption in the balance of supply and demand in all major freight sections.

To implement effective financing, it is necessary to be able to invest at the right time, in the right type of ship, have the right number and size of ships on the lines, and manage more efficiently than competitors.

In addition, every time when a company tries to attract a new amount of investment, financial intermediaries increase interest rates. In the event of a restructuring, lenders require the presence of a professional restructuring firm to help them examine the volume of possible revenues and form plans for recapitalizing the business that undoubtedly increases costs. Attracting capital from new investors can lead to significant dissolution for existing investors and in many cases to a complete change in the control of the company.

The state of the entire world economy is not particularly conducive to overcoming the problem accumulated in the maritime industry.

Despite complex and contradictory macroeconomic realities, the world's maritime trade demonstrates posi- 
tive dynamics without significant fluctuations and failures (Fig. 3).

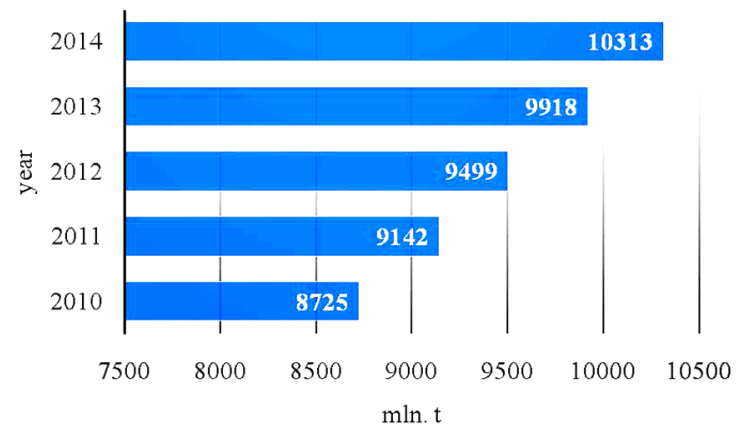

Fig. 3. Dynamics of world shipping of goods by sea, mln. $t$ (source [8])

Banks know that the value of the ship at the end of the building process will be underestimated compared to the size of the loan and reluctantly make final calculations. Most financial institutions that finance shipping companies are in the Eurozone, and some have problems with formation of the necessary financial resources, as a result, this may affect the cost of the proposed resources.

Some banks do not want to finance transactions with the acquisition of old ships [3]. In addition, the crediting of such agreements is associated with the complexity of efficiency calculation due to the increase in the price of resources.

Shipping companies are currently faced with significantly worsened economic prospects due to the state of the market for cargo transportation services, and changes in charter rates. As a result, many companies decide on restructuring or refinancing.

For port companies, raising additional funds is also a difficult issue. Some companies actively invested in the development of infrastructure and in other non-current assets faced with losses due to changes in the structure and volume of freight flows.

Commercial structures provide a wide range of services, including urgent loans. The high cost of the necessary equipment for port and shipping companies forces its owners to use borrowed funds to finance the building or purchase of a new ship. Although the share of bank loans is relatively small compared to other ways of attracting resources (sale of shares, bonds), it is loans that are the main source of short-term and medium-term loans. The profit of a commercial bank is, first of all, income in the form of interest on loans. Thus, it is necessary to take exceptionally seriously the procedure for selecting a partner bank. Debt financing is probably the most popular source of financing, as it is a more flexible form and does not take ownership of the owner.

The key directions of the commercial term loan are:

Loan duration. A loan can be offered for a shorter period of two to fifteen years, depending on the circumstances. Loans for some types of ships can be more than fifteen years.

The percentage of the loan: the ratio of the loan to the value of the asset, that is, the value of the ship is an important factor as to which credit line the bank is willing to open. Different banks have different policies that take into account the type of ship, the age and the influence of other factors on the shipping business. The loan amount that the bank is ready to offer will change, the loan will be from $40 \%$ to $80 \%$ of the company's assets, sometimes schemes where $100 \%$ financing is possible through complicated financial schemes.

Effective use of the leasing mechanism for asset modernization is possible if the main aspects are taken into account:

- leasing holder should be satisfied with the lessee, and so, whether he can fulfill his obligations under the lease agreement;

- changes in tax legislation may be a problem;

- tax schemes often complicate the mechanism by including a large package of necessary documentation.

Due to the nature of the isolation of the international maritime transport market, and given the complexity and uncertainty of both internal and external circumstances, transport companies should analyze, evaluate and judge from various elements so that they can monitor the decisionmaking process and maximize the benefits and favorable outcome. This will reduce the risks of financing.

Some financial institutions prefer to invest in very profitable operations to finance port companies.

In general, the financial condition of transport companies is characterized by a low level of sustainability. This necessitates the development of scientifically sound procedures for financial management at the companies of the industry, taking into account the specifics of transport, and, first of all, the methods of financial planning.

Companies need a rational system for formation of financial flows, that is, financial planning, which allows to make informed management decisions and minimize financial risks.

The financial planning process should take into account the industry specific features of their activities.

Principles of financial planning include:

1. The soundness of financial planning. Before the operation, it is necessary to have information about where it can find potential investors, and the forecast for financial costs.

2. Complexity of financial planning. It is necessary to take into account not only the interest rate, but also the time and resources needed to conduct the search, as well as the possible losses associated with the incompleteness and imperfection of the information received

3. Flexibility of financial planning.

4. Efficiency of financial planning.

5. Development of procedures for prompt budget adjustments.

\section{SWOT analysis of research results}

Strengths. The strength of research is to identify the current state of the financial market in order to attract additional financing from transport companies and identify the most relevant components of the financial planning process for transport companies.

Weaknesses. The weak side is that the data concerning the conditions for obtaining loans with commercial information does not allow to systematize and study more thoroughly the financial costs of transport companies.

Opportunities. The opportunities for further research are borrowing the experience of foreign countries in improving the conduct of risk analysis when obtaining funding.

Threats. The threats to the results of conducted research are that the conditions for attracting financial resources 
are constantly changing. The globalization of the capital market at the present stage of development does not just require the presentation of objective and detailed financial information, but also provides conditions for comparability of this information at the international level.

\section{Conclusions}

1. The market state from the perspective of financing port and shipping companies is researched. For financial institutions investing in transport companies is more risky than in other sectors of the economy. Companies have a heavy asset structure, increasing the level of risk.

2. The prospects of the industry development for the current year are analyzed. Moderate recovery is expected in 2017, however, if commodity markets are not activated, then an increase in activity volumes for transport companies is also undefined.

3. The main rules for financing its activities for the transport industry are a moderate amount of necessary capital, the search for the optimal cost of financing capital investments, taking into account the additional financial costs in the conditions of formation of the optimal capital structure. The most important is consideration of a changing the way of capital attraction.

\section{References}

1. Vainilovich, A. V. Finansovoe planirovanie na predpriiatiiah gruzovogo avtotransporta [Electronic resource]: $\mathrm{PhD}$ thesis / A. V. Vainilovich. - St. Petersburg, 2005. - Available at: \www/ URL: http://economy-lib.com/finansovoe-planirovanie-na-predpriyatiyah-gruzovogo-avtotransporta\#ixzz4fjZ9oR9m

2. Bazetska, H. I. Finansy pidpryiemstva: planuvannia ta upravlinnia u vyrobnychoi sferi [Electronic resource] / H. I. Bazetska, L. H. Subotovska, Yu. V. Tkachenko. - Kharkiv: KhNAMH, 2012. - 293 p. - Available at: \www/URL: http://eprints.kname. edu.ua/27132/1/Фінанси\%20підприємства\%20посібник.pdf

3. Rohovyi, A. V. Osoblyvosti planuvannia potreby finansovykh resursiv aktsionernoho tovarystva [Text] / A. V. Rohovyi // Naukovi pratsi Natsionalnoho universytetu kharchovykh tekhnolohii. - 2008. - № 24. - P. 88-90.

4. Day, R. Financial distress in the shipping sector [Electronic recourse] / R. Day, H. Theochari, N. Kuhlwein von Rathenow // Financier Worldwide. - January 2012. - Available at: \www/URL: http://www.financierworldwide.com/financialdistress-in-the-shipping-sector/\#.V1hShruLTIU

5. Global Economic Prospects. Weak Investment in Uncertain Times [Electronic recourse] // The World Bank Group. 2017. - Available at: \www/URL: http://www.worldbank.org/ en/publication/global-economic-prospects

6. Lending interest rate (\%) [Electronic recourse] // The World Bank Group. - 2016. - Available at: \www/URL: http://data. worldbank.org/indicator/FR.INR.LEND?locations=UA-DE-EE
7. «Bankovskaia vesna». Kakie budut v Ukraine stavki po kreditam i chto proizoidet $\mathrm{s}$ kursom dollara [Electronic resource] // HYSER. - 10.01.2017. - Available at: \www/URL: http:// hyser.com.ua/business_and_finance/bankovskaya-vesna-kakiebudut-v-ukraine-stavki-po-kreditam-i-chto-proizojdet-s-kursomdollara-153134

8. Mirovoe sudohodstvo i sudostroenie: sostoianie i perspektivy [Electronic resource] // Morskoi flot. - 2015. - № 4. - Available at: \www/URL: http://www.morvesti.ru/analitics/detail. php? ID $=58975$

9. Bowersox, D. J. Logistical Management: The Integrated Supply Chain Process [Text] / D. J. Bowersox. - McGraw-Hill Companies, 1996. - $752 \mathrm{p}$.

10. Ross, S. Fundamentals of Corporate Finance [Text] / S. Ross, R. Westerfield, B. Jordan. - Ed. 11. - McGraw-Hill Education, 2015. - $1008 \mathrm{p}$.

11. Filina, V. N. Transportnaia logistika: sovremennye problemy i napravleniia razvitiia [Text] / V. N. Filina // Problemy prognozirovaniia. - 2004. - № 1. - P. 110-133.

12. Shandova, N. V. Rozrobka mekhanizmu upravlinnia stiikym rozvytkom pidpryiemstv mashynobuduvannia [Text] / N. V. Shandova // Aktualni problemy ekonomiky. - 2007. - № 2. P. $101-105$

\section{АНАЛИЗ УЧЕТА УРОВНЯ ФИНАНСОВЫХ РАСХОДОВ В ПРОЦЕССЕ ФИНАНСОВОГО ПЛАНИРОВАНИЯ ТРАНСПОРТНЫХ ПРЕДПРИЯТИЙ}

Предметом работы являются практические аспекты финансового планирования транспортных компаний. Проведен анализ факторов влияния на параметры процесса финансирования капиталоемких предприятий, к которым относятся портовые предприятия и судоходные компании. Рассмотрены состояние и условия на финансовых рынках для привлечения дополнительного финансирования в первую очередь для судоходных компаний. Изменения условий финансирования необходимо учитывать в процессе финансового планирования, прежде всего уровень финансовых затрат и уровень риска.

Ключевые слова: финансовые затраты, финансирование капиталоемких предприятий, финансовое планирование, уровень риска.

Shiryaeva Ludmila, Doctor of Economic Sciences, Professor, Department of Financial and Economic Security, Accounting and Audit, Odessa National Marine University, Ukraine, ORCID: https://orcid.org/ 0000-0003-3241-7428

Khotyeyeva Natalia, PhD, Associate Professor, Department of Financial and Economic Security, Accounting and Audit, Odessa National Marine University, Ukraine, ORCID: https://orcid.org/00000002-3858-6540

Chiz Ludmila, PhD, Associate Professor, Department of Financial and Economic Security, Accounting and Audit, Odessa National Marine University, Ukraine, ORCID: https://orcid.org/0000-0002-8067-2346

Bondarenko Veronika, Odessa National Marine University, Ukraine, ORCID: http://orcid.org/0000-0003-3466-4924 